\title{
Functional capacity and quality of life of patients with chronic wounds
}

\section{Capacidade funcional e qualidade de vida de pacientes com feridas crônicas}

\section{Capacidade funcional e qualidade de vida de pacientes com feridas crônicas}

Aline Costa de Oliveira, Andressa dos Santos Alvarenga, Franciane de Sousa Freitas, Daniel de Macêdo Rocha, Sandra Marina Gonçalves Bezerra, Lídya Tolstenko Nogueira

ORCID IDs

Oliveira AC (ID https://orcid.org/0000-0003-1738-4808

Alvarenga AS (iD https://orcid.org/0000-0001-7343-0560

Freitas FS (iD https://orcid.org/0000-0002-9595-6659

Rocha DM (iD https://orcid.org/0000-0003-1709-2143

Bezerra SMG (iD https://orcid.org/0000-0003-3890-5887

Nogueira LT (D) https://orcid.org/0000-0003-4918-6531

\section{COMO CITAR}

Oliveira AC, Alvarenga AS, Freitas FS, Rocha DM, Bezerra SMG, Nogueira LT. Capacidade funcional e qualidade de vida de pacientes com feridas crônicas. ESTIMA, Braz. J. Enterostomal Ther., 16: e2918. https://doi.org/10.30886/estima.v16.612

\begin{abstract}
Objective: To evaluate functional capacity and quality of life (QoL) of patients with chronic wounds. Methods: A cross-sectional analytical study composed of 74 patients with chronic wounds accompanied at a reference center for the treatment of complex wounds in Teresina, state of Piaui. Data were collected using the Katz index and the Cardiff Wound Impact Schedule. Results: Among the domains, the "well-being" had a lower mean score and the degree of dependence obtained a significant association with the well-being and "social life" domains. The bathing, dressing, personal hygiene and locomotion activities showed an association between the domains of QoL. Conclusion: The degree of independence in performing the basic activities of daily living, especially bathing, dressing and personal hygiene, presented higher scores between domains, indicating a better QoL. It is expected that the implantation of measures that help to preserve the functional capacity will improve the patients' QoL.
\end{abstract}

DESCRIPTORS: Wounds and injuries; Quality of life; Daily activities; Stomatherapy. 


\section{RESUMO}

Objetivo: Avaliar a capacidade funcional e a qualidade de vida (QV) de pacientes com feridas crônicas. Métodos: Pesquisa de caráter transversal analítico composta por 74 pacientes com feridas crônicas acompanhadas em um centro de referência para tratamento de feridas complexas em Teresina, estado do Piauí. Para coleta de dados, utilizaram-se os instrumentos índice de Katz e Cardiff Wound Impact Schedule. Resultados: Dentre os domínios, o "bem-estar" apresentou menor escore médio e o grau de dependência obteve associação significativa com os domínios bem-estar e "vida social". As atividades banho, vestir-se, higiene pessoal e locomoção apresentaram associação entre os domínios de QV. Conclusão: O grau de independência em realizar as atividades básicas de vida diária, com destaque para o banho, o vestir-se e a higiene pessoal, apresentaram maiores escores entre os domínios, indicando melhor QV. Espera-se que a implantação de medidas que auxiliem a preservar a capacidade funcional proporcione melhoria na QV dos pacientes.

DESCRITORES: Ferimentos e lesões; Qualidade de vida; Atividades cotidianas; Estomaterapia.

\section{RESUMEN}

Objetivo: Evaluar la capacidad funcional y calidad de vida (CV) de pacientes con heridas crónicas. Métodos: Estudio de carácter transversal analítico compuesto por 74 pacientes con heridas crónicas con seguimiento en un centro de referencia para tratamiento de heridas complejas en Teresina, Estado de Piauí. Para la recolección de datos, se utilizaron los instrumentos índices de Katz y Cardiff Wound Impact Schedule. Resultados: Entre los dominios, el «bienestar» presentó menor puntuación promedio y el grado de dependencia obtuvo asociación significativa con los dominios bienestar y «vida social» Las actividades del baño, vestirse, higiene personal y movilidad presentaron asociación entre los dominios de CV. Conclusión: El grado de independencia para realizar las actividades básicas de vida diaria, destacando las del baño, vestirse y la higiene personal, presentaron mayores puntuaciones entre los dominios, indicando mejor CV. Se espera que la implementación de medidas que ayuden a preservar la capacidad funcional proporcione mejora en la CV de los pacientes.

DESCRIPTORES: Heridas y lesiones; Calidad de Vida; Actividades cotidianas; Estomaterapia.

\section{INTRODUCTION}

Chronic wounds refer to skin injurys with delayed healing, comprising a period of more than 6 weeks and presenting a high rate of recurrences. These wounds are characterized by a delay in the physiological repair that leads to a pathological inflammatory state and causes physical, psychosocial and economic changes in people affected by them ${ }^{1,2}$.

Wounds chronification has become a concern both for health professionals and health systems because it is associated with continuous, expensive and prolonged treatments, with inevitable consequences in the different dimensions of the patient's/family life and, consequently, in their quality of life (QoL) and functional capacity ${ }^{3}$.

Chronic wounds can cause pain, edema and impair mobility, factors that negatively affect patients' functional capacity, since its lead problems related to social interaction, loss of self-esteem, poor self-care, and, consequently, compromise $\mathrm{QLL}^{4}$.
The QoL includes “the individual's perception of their position in life, in the context of the culture and value systems in which they live, and in relation to their goals, expectations, standards and concerns" ${ }^{5}$. The evaluation of QoL is considered a measure of health outcome, since it attends to the assumption of individualizing attention and considering the subjectivity of the person attented $^{6}$, making clear the necessity to realize studies that cover this subject and the therapeutic alternatives existing nowadays ${ }^{7}$.

According to the international classification of commitment, disabilities and disadvantages of World Health Organization (WHO), functional capacity is considered the absence of difficulties in performing daily activities $^{8}$. Functional capacity is fundamental for the maintenance of the well-being and the autonomy of the people and the presence of the wounds can develop or influence a situation of dependence, negatively affecting 
the physical, social and psychological dimensions directly related to the QoL. Thus, the functional capacity assessment allows to investigate the independence to perform the basic activities and becomes relevant in determining the health conditions of people and in the development of interventions to improve their lives 9

It should be emphasized that there are still few studies that approach QoL and functional capacity in people with chronic wounds, however, understanding the conditions lived by this population is fundamental to health professionals, since the process of slow wound repair causes loss of selfesteem and disabilities condition ${ }^{4}$. Thus, the necessity for professional support is emphasized, mainly in changes of conduct based on the real needs of patients, prioritizing the reduction of complications, besides helping in the processes of acceptance and adaptation.

Therefore, the objective of this study was to evaluate the functional capacity and QoL of patients with chronic wounds.

\section{METHODS}

A descriptive, cross-sectional, analytical study with a quantitative approach developed at a reference center for treatment of complex wounds in Teresina, state of Piaui, Brazil, from February to May 2017. The population was consisted of patients attented at the outpatient clinic complex wounds for evaluation and treatment of the injury during the period of data collection, totaling 74 patients. As inclusion criteria, it were considered people aged 18 years or older and with a injury duration of more than 6 weeks, and the exclusion criteria were focused on people with cognitive impairment to complete the questionnaires and on the elderly who did not reach the minimum score in mental assessment.

The data collection was guided by a form adapted for sociodemographic characterization (gender, age, origin, marital status, income and schooling) and clinical (risk factors, etiology, anatomical location, time of existence, tissue type, quantity and appearance of the exudate, initial and final extension, coverages and products used and frequency between exchanges) ${ }^{10}$ and by the Mental Assessment Questionnaire ${ }^{11}$ applied to people aged 60 years and over, being selected those who obtained at least seven hits.

Also, the Cardiff Wound Impact Schedule (CWIS) questionnaire was used to measure $\mathrm{QoL}^{12}$ and the Katz ${ }^{13}$ index for functional capacity assessment. The CWIS consists of a specific and self-validated tool, validated in the Brazilian version ${ }^{14}$, with good internal consistency (Cronbach $\alpha=0.920)$ and composed of 47 items distributed in the domains "well-being"(seven items), "physical symptoms and daily life"(24 items), "social life" (14 items) and self-assessment of $\mathrm{QoL}^{2}$. The items are classified as Likert-type scale and transformed into scores ranging from 0 to 100 , where the higher the score, will be better the $\mathrm{QV}^{12}$. The Katz index is commonly used to measure the degree of independence and functional capacity in the performance of six functions of daily life, such as: feeding, continence, transference (locomotion), go to the toilet, dressing and bathing ${ }^{13,15}$.

The data was entered into double-entry worksheets in Microsoft Office Excel and later exported to the Statistic Package for Social Sciences (SPSS) version 22 aiming the descriptive and inferential analysis. Measurements of central (mean and median), dispersion (standard deviation) and minimum and maximum values for the quantitative variables and proportions for the categorical were calculated. In the inferential analysis, the Kolmogorov-Smirnov test was performed to verify data normality, Kruskal Wallis and Mann-Whitney $U$ tests (nonparametric comparative tests), Student's t-test and analysis of variance (ANOVA) (comparative parametric tests). The significance criterion adopted in the study was the level of 5\% ( $\mathrm{p}<0.05)$.

Participants who accepted to be part of the study signed the Informed Consent Term (TCLE). This research followed the ethical and legal precepts contained in Resolution 466/2012 of the National Health Council and was approved by the Research Ethics Committee of the Federal University of Piauí under opinion 1.837.210.

\section{RESULTS}

Of the 74 participants, 39 (52.7\%) were men, 31 (41.9\%) in the $41-59$ age group and 32 retirees (43.2\%). As to mobility, 35 (47.3\%) wandered without assistance. There were predominant wounds of vasculogenic origin in 26 (35.1\%) people and traumatic in 22 (29.7\%).

About QoL, Table 1 presents the scores of the CWIS questionnaire. The domain with the lowest mean score was well-being, presenting a mean of $33.2 \pm 17.2$, while the physical symptoms domains and daily life and social life had a mean score of $66.9 \pm 17.5$ and $65.6 \pm 19.7$, respectively. 
Regarding functional capacity, it was verified that 66 (89.2\%) patients performed their basic activities of Table 1. Quality of life (QOL) domains scores of patients with chronic wounds, Teresina, state of Piaui, Brazil, $2018(n=74)$.

\begin{tabular}{lccc} 
& \multicolumn{3}{c}{ Scores } \\
\cline { 2 - 4 } Domains & $\begin{array}{c}\text { Mean } \pm \\
\text { standard deviation }\end{array}$ & Min. & Max. \\
\hline Well-being & $33.2 \pm 17.2$ & 0.0 & 85.7 \\
\hline $\begin{array}{l}\text { Physical symptoms } \\
\text { and daily life }\end{array}$ & $66.9 \pm 17.5$ & 27.1 & 94.8 \\
\hline Social life & $65.6 \pm 19.7$ & 17.9 & 100.0 \\
\hline $\begin{array}{l}\text { Current QoL } \\
\text { Satisfaction }\end{array}$ & $7.2 \pm 2.4$ & 1.0 & 10.0 \\
with QoL & $7.6 \pm 2.1$ & 1.0 & 10.0 \\
\hline
\end{tabular}

daily living. As for the association between degree of dependence and QoL, the well-being and social life domains were significant and independent people differed statistically from dependents in the social life domain (Table 2).

The evaluation of the activities of bathing, dressing, personal hygiene, locomotion, continence and feeding showed a higher frequency of independent patients in all activities (Table 3).

In relation to the basic activities of daily living and QoL, bath presented a significant association with all well-being domains $(p=0.006)$, physical symptoms and daily life $(\mathrm{p}=0.007)$ and social life $(\mathrm{p}=0.009)$.

Table 2. Association between degree of dependence and quality of life of patients with chronic wounds, Teresina, state of Piaui, Brazil, $2018(n=74)$.

\begin{tabular}{|c|c|c|c|c|c|c|c|}
\hline \multicolumn{8}{|c|}{ Cardiff Wound Impact Schedule Domains (CWIS) } \\
\hline $\begin{array}{c}\text { Degree of } \\
\text { dependency }\end{array}$ & $\mathrm{n}(\%)$ & Well-being ${ }^{*}$ & $\mathrm{p}^{\dagger}$ & $\begin{array}{l}\text { Physical symptoms } \\
\text { and daily life* }\end{array}$ & $\mathrm{p}^{\dagger}$ & Social Life ${ }^{\ddagger}$ & $p^{\S}$ \\
\hline Independent & $66(89.2)$ & $32.1(0.0-85.7)$ & & $71.9(27.1-94.8)$ & & $67.3 \pm 18.5$ & \\
\hline Intermediate & $2(2.7)$ & $48.2(39.3-57.1)$ & 0.043 & $69.79(65.6-74.0)$ & 0.087 & $72.3 \pm 3.8$ & 0.017 \\
\hline Dependent & $6(8.7)$ & $17.9(0.0-39.3)$ & & $48.9(39.6-75.0)$ & & $44.0 \pm 20.0$ & \\
\hline
\end{tabular}

"Median (minimum-maximum); ${ }^{\dagger}$ p-value of Kruskal Wallis; ${ }^{\ddagger}$ Mean \pm standard deviation; ${ }^{\S}$ Analysis of variance (ANOVA).

Table 3. Association between basic activities of daily living and domains of quality of life, Teresina, state of Piaui, Brazil, 2018 $(n=74)$.

\begin{tabular}{|c|c|c|c|c|c|c|c|}
\hline \multirow{2}{*}{$\begin{array}{l}\text { Atividades básicas } \\
\text { de vida diária }\end{array}$} & \multirow[b]{2}{*}{$\mathrm{n}(\%)$} & \multicolumn{6}{|c|}{ Cardiff Wound Impact Schedule Domains (CWIS) } \\
\hline & & Well-being ${ }^{*}$ & $\mathrm{p}^{\dagger}$ & $\begin{array}{c}\text { Physical symptoms } \\
\text { and daily life* }\end{array}$ & $\mathbf{p}^{\dagger}$ & Social Life* & $\mathrm{p}^{\dagger}$ \\
\hline \multicolumn{8}{|l|}{ Bathing } \\
\hline Independent & $69(93.2)$ & $32.1(0.0-85.7)$ & 0.006 & $72.9(27.1-94.8)$ & 0.007 & $69.6(23.2-100.0)$ & 0.009 \\
\hline Dependent & $5(6.8)$ & $14.3(0.0-28.6)$ & & $46.9(39.6-54.2)$ & & $50.0(17.9-51.8)$ & \\
\hline \multicolumn{8}{|l|}{ Dressing } \\
\hline Independent & $70(94.6)$ & $32.1(0.0-85.7)$ & 0.018 & $71.9(27.1-94.8)$ & 0.025 & $69.6(23.2-100.0)$ & 0.030 \\
\hline Dependent & $4(5.4)$ & $12.5(0.0-28.6)$ & & $48.9(39.6-54.2)$ & & $50.0(17.9-51.8)$ & \\
\hline \multicolumn{8}{|l|}{ Personal hygiene } \\
\hline Independent & $67(90.5)$ & $32.1(0.0-85.7)$ & 0.165 & $68.2 \pm 17.4 \S$ & $0.056 \ddagger$ & $67.3 \pm 18.7 \S$ & $0.015 \ddagger$ \\
\hline Dependent & $7(9.5)$ & $17.9(0.0-57.1)$ & & $54.9 \pm 14.2 \S$ & & $48.5 \pm 21.7 \S$ & \\
\hline \multicolumn{8}{|l|}{ Locomotion } \\
\hline Independent & $67(90.5)$ & $31.1(0.0-85.7)$ & 0.099 & $72.9(27.1-94.8)$ & 0.034 & $69.6(25.0-67.4)$ & 0.024 \\
\hline Dependent & $7(9.5)$ & $17.9(0.0-39.3)$ & & $51.0(39.6-75.0)$ & & $50.0(17.9-47.7)$ & \\
\hline \multicolumn{8}{|l|}{ Continence } \\
\hline Independent & $71(95.9)$ & $32.1(0.0-85.7)$ & 0.086 & $69.8(27.1-94.8)$ & 0.366 & $69.4(17.9-100.0)$ & 0.388 \\
\hline Dependent & $3(4.1)$ & $17.9(7.1-28.6)$ & & $54.2(46.9-75.0)$ & & $51.8(50.0-71.4)$ & \\
\hline \multicolumn{8}{|l|}{ Feeding } \\
\hline Independent & $72(97.3)$ & $32.1(0.0-85.7)$ & 0.170 & $70.3(27.1-94.8)$ & 0.172 & $69.6(17.9-100.0)$ & 0.243 \\
\hline Dependent & $2(2.7)$ & $17.9(7.1-28.6)$ & & $50.5(46.9-54.2)$ & & $50.9(50.0-51.8)$ & \\
\hline
\end{tabular}

*Median (minimum-maximum); ${ }^{\star}$ Mann Whitney $U$ test; ${ }^{\ddagger}$ Student $t$ test; ${ }^{\S}$ Mean \pm standard deviation 
Dressing was associated with well-being domains $(\mathrm{p}=0.018)$, physical symptoms and daily life $(\mathrm{p}=$ $0.025)$ and social life $(p=0.030)$. Personal hygiene was positively associated with the social life domain ( $p=$ $0.015)$ and locomotion was significant when associated with physical symptoms and daily life domains $(\mathrm{p}=$ $0.034)$ and social life $(p=0.024)$.

\section{DISCUSSION}

The characterization of the sociodemographic variables identified that the majority of the patients were men and located in the age group between 41-59 years, generating direct repercussions in the health services and in the home environment, since the chronicity of the wounds promotes the increase of costs and leads to the distancing of work activities or early retirement ${ }^{5}$, which is the predominant occupational situation in the study participants.

About $47.3 \%$ of the studied population wandered without assistance and had wounds of vasculogenic origin. These injuries are usually accompanied by intense pain, exudate, and odor, with slow healing that, together with psychosocial factors and care dependence, affects functional capacity and affects QoL ${ }^{16,17}$.

The well-being domain presented lower mean QoL score, while the physical symptoms domains and daily life and social life had similar and higher average scores. These results are consistent with other studies that also used the CWIS questionnaire to assess the QoL of people with wounds ${ }^{18,19}$.

Well-being is related to anxiety levels, involving emotional perception that is related to the existence of positive emotions and absence of negative emotions, involving factors such as life satisfaction, confrontation skills, optimism and perspective for the future ${ }^{19,20}$. Patients with ulcers often experience negative emotions such as shame, embarrassment, depression, concern that the condition worse, apathy and mental problems, coexisting with a strong feeling of loneliness ${ }^{6}$.

Other studies also revealed a negative impact of skin injuries on QoL related to the emotional sphere, especially in patients with chronic ulcers ${ }^{6,21}$. The progressive and chronic character of wounds affects the most important spheres of human life, and it is important to have comprehensive care covering all aspects of impaired functioning in the physical, psychosocial and emotional spheres $^{22}$.

In the present study, the functional capacity was also evaluated, identifying a low impact in relation to the degree of dependence, since $89.2 \%$ of the people presented themselves independently for all activities ${ }^{23}$. However, when associated with QoL, the well-being and social life domains were significant.

Previous studies have shown that long-term disabilities, particularly those that affect routine daily activities, have an indirect correlation with mental health and $\mathrm{Qol}^{24,25}$. Relying on other people for the performance of daily topics is a predictable outcome in the face of compromised QoL. Thus, providing adequate services to these people can reduce their dependence and have a positive impact on their QoL increase ${ }^{25}$.

The results show that most of the participants did not present difficulties in the bath, to dress themselves, to perform their personal hygiene, in locomotion, continence and feeding. These daily activities do not directly interfere with the life of patients with chronic wounds, since to perform these activities, the upper limbs are also used, the region of the body less affected by wounds ${ }^{26}$.

In the case of daily activities, the bath presented association in all areas of well-being, physical symptoms and daily life and social life. The act of dressing presented association with the domains well-being, physical symptoms and daily life and social life. Personal hygiene was positively associated with social life domain and locomotion was significant when associated with domains physical symptoms and daily life and social life. It is worth highlighting that in the literature the relationship between the presence of wounds and the compromise of well-being is evident, since physical limitations and difficulties in the development of daily, social and work activities are common, as well as dependence on care ${ }^{27}$.

The presence of self-care impairments was evidenced by difficulties in wandering, dressing and bathroom use, also verified in other studies that evaluated the impact of the injury on patients' functional capacity ${ }^{28}$. Thus, it is considered that this problem may directly reflect on care for their own wound, presuming the dependence on care and the continued need for support from family members and health professionals. 
According to the literature, the reason for the limitations of daily activities in patients with wounds is also influencing dressings, recurrences and a high time of treatment that can cause difficulties in moving or the necessity to prevent complications $^{29}$. In addition, these limitations may be associated with the presence of severe pain and exudation and unpleasant wound smell ${ }^{6}$, thus influencing lower levels of QoL and impairment of functional capacity.

\section{CONCLUSION}

This study demonstrated that the presence of chronic wounds negatively affects the QoL of the patients and that the well-being domain interfered directly for worse QoL, generating physical, social and emotional impacts. In addition, it was observed a significant degree of independence in performing the basic activities of daily living, with emphasis on bathing, dressing, personal hygiene and higher scores between domains, which led to an improvement in QoL.
Thus, the implantation of measures that help to preserve the functional capacity and that provide the accomplishment of the daily activities and of the selfcare implies in the possibility of an autonomous and socially active life. In this way, future research focusing on comprehensive interventions that promote the rehabilitation of wounded people in the execution of their activities and the improvement of QoL is necessary.

\section{AUTHOR'S CONTRIBUTION}

Conceptualization, by Oliveira AC and Rocha DM; Methodology, by Oliveira AC and Rocha DM; Investigation, Alvarenga AS and Freitas FS; Writing - First version, by Oliveira AC; Alvarenga AS and Freitas FS; Writing - Review \& Editing, Nogueira LT and Bezerra SMG; Financing acquisition, by Oliveira AC; Alvarenga AS and Freitas FS; Resources, Bezerra SMG; Supervision, Nogueira LT.

\section{REFERENCES}

1. Markova A, Mostow EN. US skin disease assessment: ulcer and wound care. Dermatol Clin. 2012;30(1):107-11. https:// doi.org/10.1016/j.det.2011.08.005.

2. Shubhangi VA. Chronic leg ulcers: epidemiology, aetiopathogenesis and management. Ulcers. 2013;2013:1-9. https://doi.org/10.1155/2013/413604.

3. Mestre T, Rodrigues A, Cardoso J. Cicatrização de feridas crônicas: algumas opções terapêuticas. Rev SPDV. 2012;70(4):423-31. https://doi.org/10.29021/spdv.70.4.96.

4. Joaquim FL, Camacho ACLF, Sabóia VM, Santos RC, Santos LS, Nogueira GA. Impacto da visita domiciliar na capacidade funcional de pacientes com úlceras venosas. Rev Bras Enferm. 2016;69(3):468-77. https://doi.org/10.1590/0034$7167.2016690308 \mathrm{i}$.

5. The WHOQOL Group. World Health Organization quality of life assessment (WHOQOL): position paper from World Health Organization. Soc Sci Med. 1995;41(10):1403-9. https://doi.org/10.1016/0277-9536(95)00112-K.

6. Szewczyk MT, Moscicka P, Jawien A, BialaskJC, Cierzniakowsk K, Slusarz R, et al. Quality of life in patients with leg ulcers or skin lesions-A pilot study. Postępy Dermatol Allergol. 2015;32(6):465-9. https://doi.org/10.5114/pdia.2014.40983.

7. Paula GR, Souza BN, Santos LF, Barbosa MA, Brasil W, Oliveira LMAC. Qualidade de vida para a avaliação de grupos de promoção da saúde. Revista Bras Enferm. 2016;69(2):242-9. https://doi.org/10.1590/0034-7167.2016690206i.

8. Alves LC, Leite IC, Machado CJ. Conceituando e mensurando a incapacidade funcional da população idosa: uma revisão de literatura. Ciênc saúde coletiva. 2008;13(4):1199-207. https://doi.org/10.1590/S1413-81232008000400016.
9. Joaquim FL, Camacho ACLF, Silva RMCRA, Leite BS, Queiroz RS, Assis CRC. Impact of home visits on the functional capacity of patients with venous ulcers. Rev Bras Enferm. 2017;70(2):287-93.https://doi.org/10.1590/0034-7167.2016 690308i.

10. Bezerra SMG, Rocha DM, Nogueira LT. Protocolo de prevenção, avaliação e tratamento de lesões pele do serviço público municipal de Teresina. Teresina: Prefeitura Municipal de Teresina; 2016.

11. Ventura MM, Bottino CMC. Avaliação cognitiva em pacientes idosos. In: Netto MP. Gerontologia. São Paulo: Atheneu; 2005. p. 89-174.

12. Price P, Harding K. The Cardiff Wound Impact Schedule: the development of a condition specific questionnaire to assess health-related quality of life in patients with chronic wounds of the lower limb. Int Wound J. 2004;1(1):10-7. https://doi. org/10.1111/j.1742-481x.2004.00007.x.

13. Lino VTS, Pereira SEM, Camacho LAB, Ribeiro Filho ST, Buksman S. Adaptação transcultural da Escala de Independência em Atividades da Vida Diária (Escala de Katz). Cad Saúde Pública. 2008;24(1):103-12. https://doi. org/10.1590/S0102-311X2008000100010.

14. Augusto FS, Blanes L, Nicodemo D, Ferreira LM. Translation and cross-cultural adaptation of the Cardiff Wound Impact Schedule to Brazilian Portuguese. J Tissue Viability. 2017;26(2):113-8. https://doi.org/10.1016/j.jtv.2016.12.002.

15. Katz S, Akpom CA. A measure of primary sociobiological functions. Int J Health Serv. 1976;6(3):493-508. https://doi. org/10.2190/UURL-2RYU-WRYD-EY3K. 
16. Bedin LF, Busanello J, Sehnem GD, Silva FM, Poll MA. Estratégias de promoção da autoestima, autonomia e autocuidado das pessoas com feridas crônicas. Rev Gaúcha Enferm. 2014;35(3):61-7. https://doi.org/10.1590/19831447.2014.03.43581.

17. Isaac A, Watson C. How venous leg ulcers affect quality of life. Prim Health Care. 2016;26(3):18-23. https://doi. org/10.7748/phc.26.3.18.s30.

18. Kapp S, Santamaria N. The financial and quality-of-life cost to patients living with a chronic wound in the community. Int Wound J. 2017;14(6):1108-20. https://doi.org/10.1111/ iwj.12767.

19. Purcell A, Buckley T, Fethney J, King J, Moyle W, Marshall AP. The effectiveness of EMLA as a primary dressing on painful chroniclegulcers: effectsonwound healing and health-related quality of life. Int J Low Extrem Wounds. 2017;16(3):163-72. https://doi.org/10.1177/1534734617726678.

20. Upton D, Andrews A, Upton P. Venous leg ulcers: What about well-being? J Wound Care. 2014;23(1):14-7. https:// doi.org/10.12968/jowc.2014.23.1.14.

21. Szewczyk MT, Cwajda J, Rogala J, Jawien A. Psychological and social problems of patients with chronic venous disease. Postępy Dermatol Allergol. 2007;24(5):207-10.

22. Molski P, Kruczyński J, Molski A, Molski S. Manual lymphatic drainage improves the quality of life in patients with chronic venous disease: a randomized controlled trial. Arch Med Sci. 2013;20;9(3):452-8. https://doi.org/10.5114/ aoms.2013.35343.

23. Camacho ACLF, Santos RC, Joaquim FL, Louredo DS, Morais IM, Silva EA. Estudo comparativo sobre a capacidade funcional de pacientes adultos e idosos com úlceras venosas. J res fundam care. 2015;7(1):1954-66. https://doi. org/10.9789/2175-5361.2015.v7i1.1.

24. Vieira CPB, Furtado AS, Almeida PCD, Luz MHBA, Pereira AFM. Prevalência e caracterização de feridas crônicas em idosos assistidos na atenção básica. Rev baiana enferm. 2017;31(3):e17397. https://doi.org/10.18471/rbe. v31i3.17397.

25. Rahimi A, Mousavi B, Soroush M, Masumi M, Montazeri A. Pain and health-related quality of life in war veterans with bilateral lower limb amputations. Trauma Mon. 2012;17(2):282-6. https://doi.org/10.5812\%2Ftraumamon.5135.

26. Moreira MMR, Blanes L, Augusto FS, Filho AG, Ferreira LM. Qualidade de vida e capacidade funcional em pacientes com úlcera arterial. Av Enferm. 2016;34(2):170-80. https:// doi.org/10.15446/av.enferm.v34n2.61617.

27. Dias TYAF, Costa IKF, Melo MDM, Torres SMSGSO, Maia EMC, Torres GV. Quality of life assessment of patients with and without venous ulcer. Rev Latino-Am Enfermagem. 2014;22(4):576-81. https://doi.org/10.1590/0104-1169.3304.2454.

28. Allami M, Yavari A, Karimi A, Masoumi M, Soroush M, Faraji E. Health-related quality of life and the ability to perform activities of daily living: a cross-sectional study on 1079 war veterans with ankle-foot disorders. Mil Med Res. 2017;4:37. https://doi.org/10.1186\%2Fs40779-017-0146-1.

29. Abreu AM, Oliveira BGR. A study of the Unna Boot compared with the elastic bandage in venous ulcers: a randomized clinical trial. Rev Latino-Am Enfermagem. 2015;23(4):571-7. https://doi.org/10.1590/0104-1169.0373.2590. 